\title{
CORPORATE GOVERNANCE IN THE EUROPEAN BANKING SECTOR: SOME REMARKS ON DIVERSITY
}

\author{
FRANCESCA ARNABOLDI \\ Dipartimento di Scienze Giuridiche "C. Beccaria" \\ Università degli Studi di Milano, Via Festa del Perdono 7 \\ 20122 Milano and CEFIN, Università degli Studi di Modena e Reggio Emilia \\ Via Berengario 51, Modena, Italy \\ farnaboldi@unimi.it
}

Accepted 5 March 2019

Published 7 May 2019

\begin{abstract}
This work discusses some of the critical aspects of bank corporate governance in the European Union. Enhancing sound corporate governance practices has become one of the major concerns in the supervisory authority's agenda and one of the critical features to evaluate banks' stability. The global rethinking about corporate governance rules has translated into a stronger focus on board diversity for EU banks. The existing literature and sound corporate governance practices support the view that different types of board members may bring different capabilities to their banks. Even if board diversity may add complexity to the functioning of the board, the advantages it brings are of utmost importance in the challenging environment banks are facing. This work highlights the fragmentation of the EU corporate governance rules as banks have to comply with 27 sets of different regulations and codes. This complexity should not be ignored, as member states' specificities, legal systems, and a more general openness to diversity influence the effect reforms may have on banks' performance and stability.
\end{abstract}

Keywords: Corporate governance; bank; board diversity.

\section{Introduction}

In recent years, corporate governance issues have received increasing attention from various international bodies. As highlighted by the Group of Thirty (2012), weaknesses in bank corporate governance mechanisms are thought to have played a vital role during the global financial crisis (GFC) in promoting bank risk-taking. The finding that corporate governance has implications for bank stability was already established long before the GFC (see among others, Saunders et al. 1990, 
Gorton \& Rosen 1995, Anderson \& Fraser 2000). Sound corporate governance is fundamental to the banking system to operate well.

The GFC brought attention, both in academic and policy circles, back to the role of bank corporate governance structures for financial stability. Recent literature investigates the impact of corporate governance on bank risk-taking (Caprio et al. 2007, Laeven \& Levine 2009, Pathan 2009, DeYoung et al. 2013). Kirkpatrick (2009) establishes that weak corporate governance in banks leads to inadequate risk management, especially insufficient risk monitoring through the board, a factor that contributed significantly to the bank instabilities during the crisis. Berger et al. (2016) show that corporate governance arrangements lead to actual bank failure. Recent academic work was aimed at identifying the most efficient bank governance structures (Adams \& Mehran 2012, Beltratti \& Stulz 2012, Mehran et al. 2011).

Policymakers have tried to address the perceived flaws of the existing bank governance structures with a series of initiatives to control bank risk-taking (Basel Committee on Banking Supervision 2014, Federal Reserve 2010, Liikanen Report 2012). Policymakers and regulators have mainly focused on specific governance shortcomings (Srivastav \& Hagendorff 2016). In the UK, the Walker Review (Walker 2009) revises board arrangements and the qualifications of board members as well as the compensation arrangements. Similarly, since 2010, the Dutch Banking Code has been addressing the selection process of bank boards, including the skill and training of board members and their remuneration. Guidance for compensation has been released, introducing restrictions on salary and perks, and disclosure of compensation (Federal Reserve 2010).

In the European Union (EU), initiatives by policymakers included an emphasis on increased diversity. CRD IV (Directive 2013/36/EU) reinforces the governance requirements for banks, highlighting the responsibility of the management body for sound governance arrangements, the importance of a robust board that challenges and monitors management decision-making, and the need to establish and implement a sound risk strategy and risk management framework. Among the enhanced corporate governance rules, CRD IV requirements promote diversity in board composition to counteract the phenomenon of groupthink. This phenomenon is partly responsible for the lack of monitoring by the board of directors of management decisions. To facilitate independent opinions and critical challenges, CRD IV recommends that the board of directors encompass sufficiently diverse age, gender, geographical provenance and educational and professional background to provide a variety of views, soft skills and experiences.

This note discusses the main features of bank corporate governance in the EU and its implications for financial stability. Section 2 reviews the recent changes in EU regulation and the challenges posed to the banking system. Section 3 focuses on board diversity and its impact on banks' stability. Section 4 concludes this paper. 


\section{Changes and Challenges in the EU Regulation on Bank Corporate Governance}

Sound governance is relevant in any organization and it is even more critical in a complex and challenging environment as the one banks are facing nowadays. Sound governance provides the necessary checks and balances; it counters excessive risktaking; it ensures that decisions are taken sustainably.

Since the beginning of the Single Supervisory Mechanism (SSM), ECB Banking Supervision has developed a comprehensive approach based on a range of tools to assess the design and implementation of sound governance in the European banking system (ECB 2018). A first tool is a fit and proper assessment which is employed to check whether banks' board members are suited to their position. The Supervisory Authority assesses their experience, reputation, independence, their time commitment and their potential conflicts of interest to ensure that they are fit and proper for the job. Secondly, governance is one of the four central elements that constitute the Supervisory Review and Evaluation Process (SREP). SREP allows the ECB, and the national supervisory authorities for the less significant banks, to analyze whether the risks that a bank takes are consistent with its risk capacity and strategic objectives by assessing banks' risk appetite framework (RAF). In particular, banks should mull the policies, processes, controls, systems, and procedures defined in their RAF over their decision-making processes and risk management. The RAF should also be aligned with banks' business plans, strategies, capital planning, and remuneration schemes. A third tool is the "deep-dive" one, that is an on-site mission, which allows the ECB to better understand specific processes or approaches related to governance and risk assessment, for instance by attending board meetings. On-site inspections are a fourth tool which is used to discuss governance and risk management with banks. The ECB also uses benchmarking, for example, through thematic reviews. A thematic review on governance and risk appetite addressed the topic from various angles, such as risk culture, the composition, and organization of the board of directors and decision-making (ECB, 2016). The findings of the supervisory tools can be used to fine-tune the SREP methodology.

According to ECB (2018), despite significant achievements, banks still need to make improvements on (i) the fit and proper assessments, (ii) boards' independence, (iii) risk appetite frameworks, and (iv) risk reporting and data aggregation. As for the first aspect, the collective knowledge of the board can be improved, strengthening some areas of expertize, such as IT and accounting. In this respect, induction arrangements and ongoing training are not always sufficient to ensure risk awareness and thus foster the necessary quality of debate (ECB 2016). The quality of debate on the board, especially its capacity to independently challenge the executives, is a key element to enhance board independence. The quality of debate can be improved working on the quality of documentation, on interactions among board members and the organizations of board meetings. The ECB (2016) highlights various shortcomings, for example, that the documentation is often not sent sufficiently far in 
advance, information asymmetries among board members can reduce the quality of the debate and the time of debate is often too limited. On the design of the RAF, several banks, in particular the smaller ones, have only recently formalized and integrated the framework. Thus areas of improvements are related to the full coverage of material risk areas, in particular nonfinancial risks or profitability and business risk, and to the proper adjustment of the risk appetite metrics to the bank's business model and risk profile. Finally, it is essential that banks have effective management information systems to be able to report any limit breach adequately and promptly. Data aggregation issues impact the quality of the risk reports and hamper an effective reporting of limit breaches.

A second challenge European banks face refers to the governance rules applicable in Europe. Although various policy initiatives at the EU level aimed at improving standards of corporate governance, further harmonization and supervisory convergence are needed to ensuring a level playing field. Rules are different among member states; as a consequence, banks have to apply national law in this area facing higher compliance costs and greater complexity. Besides, the grip of nationalism on corporate law shows how governance structures matter in ways that surpass the agency cost considerations investigated in the literature (Pargendler 2019). Pressures influencing governance policies reflect differing views of capital markets and corporate purpose between shareholder and stakeholder-oriented systems. In the Netherlands, comply-or-explain code works reasonably well, assisted by the existence of a monitoring capability in this jurisdiction (Dallas \& Pitt-Watson 2016).

Nevertheless, in situations involving controlling shareholders, the lack of an enforcement mechanism may be a weakness of comply-or-explain. Minimum corporate governance standards or stricter enforcement laws at the European level might help overcome such deficiencies. However, a potential risk of attempts for further harmonization is to lower base standards to establish an acceptable common denominator across a very diverse group of countries with differing governance traditions.

\section{The Role of Diversity in Bank Corporate Governance}

Many of the post-crisis governance reforms explicitly emphasize the importance of diversity in the boardroom. Most of these initiatives are based on the view that more diverse boards, with an increased presence of women and minorities, would positively affect the governance of companies. One argument is that gender balance is of particular importance to ensure adequate representation of population and directors should be selected among a greater pool of talents. Employee representation in the boardroom could also, by adding a different perspective and knowledge of the internal workings of companies, be seen as a positive way of enhancing diversity.

More diverse boards should more effectively monitor management and therefore contribute to improved risk oversight and resilience of banks. They can also help improve decision-making regarding strategies and risk-taking by facilitating a 
broader range of views, opinions, experience, perception, values and backgrounds. Directive 2013/36/EU recommends that diversity is one of the criteria for the composition of boards and should also be addressed in banks' recruitment policy more generally.

Despite a general call for greater diversity, EBA (2016) shows that in most member states, a relatively low number of banks have adopted a diversity policy. Most frequently, banks do not indicate a timeline within which they intend to achieve diversity targets. Evidence suggests that soft law regulation aimed at improving the participation of women and minorities in high profile roles have had little impact. Therefore, several European regulators recommend gender quotas for publicly listed companies' boards. In this respect, a widely studied case outside the EU is the Norwegian one. In 2003, the Norwegian Parliament passed a soft law requiring all public limited companies to have at least $40 \%$ of women on their boards of directors. After voluntary compliance failed, the requirement became law in 2006, with a twoyear transition period and liquidation as a penalty for noncompliance. Following Norway's example, some European countries, including Belgium, France, Italy, the Netherlands, Spain and Germany, have since promoted legislation aiming to increase gender diversity on corporate boards via the imposition of quotas. The EU Commission has discussed a gender quota of $40 \%$ for all large EU companies following the Norwegian experience. The effect of reforms on bank performance is however complex to disentangle. Arnaboldi et al. (2018b) document that reforms increase bank stock returns up to two years after their introduction. While the impact is similar across mandatory regulation and soft law, the effectiveness of reforms depends on a country's institutional environment, its legal origin and its cultural openness to diversity.

The "one size does not fit all" finding may help explain the mixed empirical evidence on diversity. The literature has documented that board characteristics are not exogenous random variables but are endogenously chosen by firms (Hermalin \& Weisbach 2003, Adams \& Ferreira 2012, Sila et al. 2016). With some exceptions, most studies on the impact of board features on firm performance have excluded financial firms from their analysis due to their regulated nature. Further, literature has mainly investigated the US (see, among others, Adams \& Funk 2012, Hagendorff \& Keasey 2012, Sila et al. 2016) or a single country (for example, Berger et al. 2014, Huyghebaert \& Wang 2017).

Recently, de Cabo et al. (2012), Garcia-Meca et al. (2015), Farag \& Mallin (2017) have studied the impact of board diversity features on European banks' performance. The nationality of directors is one of the main characteristics of board diversity. The increasing internationalization of business leads to higher demand for directors who possess the necessary knowledge and contacts in foreign markets to link the bank to the different contexts of the countries in which it operates (Carpenter et al. 2001). The literature suggests that foreign directors go beyond financial contributions and extend to the provision of managerial expertize and 
technical collaborations increasing creativity and innovation (Ezat \& El-Masry 2008, Samaha et al. 2012).

The increasing pressure for gender diversity may be one of the factors explaining the growing number of women in the boardroom (Farrell \& Hersch 2005, Dunn 2012). However, very often banks show a tokenism behavior: once the target is met with one woman on the board, there are no further hires of women to the board, because "token" board member is seen as representing the "minority" in general (Kanter 1977). Literature provides evidence supporting the existence of tokenism. On a sample of Chinese firms, Liu et al. (2014) show that firm performance is positively related to gender diversity, but there must be a critical mass of at least three women to obtain a positive effect. Besides, the economic, legal and cultural environment banks that operate may affect the diversity-performance relationship. Garcia-Meca et al. (2015) find evidence that gender diversity improves financial performance, especially in those banks located in countries with high investor protection and strong bank regulation. Based on this evidence, the authors support public policy initiatives for quotas of women on corporate boards.

EBA (2016) considers gender diversity a key aspect of diversity, as different attitudes and behaviors can be observed in persons of different gender. The same holds for age, as the period in which a person has grown up influences his or her values, skills, experiences, social networks, and risk culture. By increasing the age diversity of the board of directors, the board's aggregated human and social capital can be maximized with a positive impact on performance (Carter et al. 2010). On the other hand, Westphal \& Zajac (1995) argue that CEOs prefer to work with demographically similar board directors. Thus, CEOs who can influence the directors' nomination process will try to hire directors who are demographically similar to themselves. Furthermore, member states show different demographical structures, which may affect the age of board members. To this extent, the supervisory authority encourages to selecting board members of different age to enhance board diversity.

Geographical provenance of directors should also be taken into consideration (EBA 2016). Directors coming from international backgrounds may understand the cultural values, market specificities and legal frameworks present in the central business hubs the banks are active in, and facilitate informed decision-making regarding the business strategy within those foreign countries and areas. While substantial board internationalization increase complexity and may hurt bank performance, the presence of foreign directors appears to be less detrimental during a financial crisis and in countries that are more welcoming towards diversity (Arnaboldi et al. 2018a).

An additional diversity feature relates to education and previous experiences of the directors. Education and professional background of board members have an influence on their perceptions and hence their decisions stand with direct implications for corporate risk-taking and the decision-making process (Hambrick 2007, Li \& Tang 2010, Sanders \& Hambrick 2007). Farag \& Mallin (2018) find a positive and significant relationship between both CEO higher education and their 
previous board experience and corporate risk-taking. CEOs' professional background has a positive impact on private companies' innovation in China (Lin et al. 2011). Terjesen et al. (2009) using the human capital theory of Becker (1964) argue that an individual's education, skills, and experience frame their cognition and productivity. Board members with law backgrounds may have a better perception of legal aspects and regulations as opposed to members with accounting backgrounds who might be more knowledgeable about financial issues. Different human capital may bring different experiences to the board enriching the overall company (Hillman et al. 2000).

\section{Conclusion}

This paper discusses some of the critical aspects of bank corporate governance in the EU. Three main conclusions can be drawn from the analysis. First, the relevance of the board of directors has increased since the establishment of the Banking Union. The board of directors is responsible for banks' major strategic decisions and for ensuring that its franchise value can survive outside shocks. The ability of the board to perform the monitoring, advisory and resource provisioning functions depends crucially on the complexity of the operational structure of the bank and the conditions of the external environment. The GFC highlighted the flaws in the functioning of the board of directors which reflected in banks' excessive risk-taking. Enhancing sound corporate governance practices has become one of the major concerns in the supervisory authority's agenda and one of the key features to evaluate banks' stability.

Second, the global rethinking about corporate governance rules has translated into a stronger focus on board diversity for EU banks. Literature and sound corporate governance practices support the view that different types of board members may bring different resources to their banks. Hence more diverse boards are likely to bring different sets of intangible resources to their banks. Even if board diversity may add complexity to the functioning of the board, the assets it brings are of utmost importance in the challenging environment banks are facing. Banks should see board diversity as an opportunity to gather skills and experiences, which can benefit all stakeholders.

Third, regulatory authority faces challenges to ensure the level playing field. In the EU corporate governance rules are still fragmented, and banks have to comply with 27 sets of different regulations and codes. Regulators should, however, consider that one size does not fit all and member states' specificities, legal systems, and a more general openness to diversity influence the effect reforms may have on banks' performance and stability.

\section{References}

R. B. Adams \& D. Ferreira (2012) Regulatory pressure and bank directors' incentives to attend board meetings, International Review of Finance 12(2), 227-248. 
R. B. Adams \& P. Funk (2012) Beyond the glass ceiling: Does gender matter? Management Science 58, 219-235.

R. B. Adams \& H. Mehran (2012) Bank board structure, and performance: Evidence for large bank holding companies, Journal of Financial Intermediation 21, 243-267.

R. C. Anderson \& D. R. Fraser (2000) Corporate control, bank risk taking and the health of the banking industry, Journal of Banking and Finance 24, 1383-1398.

F. Arnaboldi, B. Casu, E. Kalothychou \& A. Sarkisyan (2018a) The performance effects of board heterogeneity: What works for EU banks? European Journal of Finance doi: 10.1080/1351847X.2018.1479719.

F. Arnaboldi, B. Casu, E. Kalothychou \& A. Sarkisyan (2018b) Board diversity reforms: Do they matter for EU bank performance?, Centre for Banking Research Working Paper Series WP 03/18, Cass Business School City, University of London

Basel Committee on Banking Supervision (2014) Corporate governance principles for banks. Basel: Bank for International Settlements.

G. Becker (1964) Human Capital. Chicago, IL: University of Chicago Press.

A. Beltratti \& R. M. Stulz (2012) The credit crisis around the globe: Why did some banks perform better?, Journal of Financial Economics 105 (1), 1-17.

A. Berger, B. Imbierowicz \& C. Rauch (2016) The roles of corporate governance in bank failures during the recent financial crisis, Journal of Money, Credit and Banking 48 (4), 729-770.

A. N. Berger, T. Kick \& K. Schaeck (2014) Executive board composition and bank risk taking, Journal of Corporate Finance 28, 48-65.

G. Caprio, L. Laeven \& R. Levine (2007) Governance and bank valuation, Journal of Financial Intermediation, 16, 584-617.

M. A. Carpenter, W. G. Sanders \& H. B. Gregersen (2001) Bundling human capital with organizational context: The impact of international assignment experience on multinational firm performance and CEO pay, Academy of Management Journal 44 (3), 493511.

D. A. Carter, F. P. D’Souza, B. J. Simkins \& W. G. Simpson (2010) The gender and ethnic diversity of US boards and board committees and firm financial performance, Corporate Governance 18 (5), 396-414.

G. Dallas \& D. Pitt-Watson (2016) Corporate governance policy in the European Union, CFA Institute, August, available at file:///C:/Users/Francesca/Downloads/CorporateGovernancePolicyintheEU-DPitt-Watson.pdf.

M. R. de Cabo, R. Gimeno \& M. J. Nieto (2012) Gender diversity on European banks' boards of directors, Journal of Business Ethics 109 (2), 145-162.

R. DeYoung, E. Y. Peng \& M. Yan (2013) Executive compensation and business policy choices at US commercial banks, Journal of Financial and Quantitative Analysis 48, 165-196.

P. Dunn (2012) Breaking the boardroom gender barrier: The human capital of female corporate directors, Journal of Managerial Governance 16, 557-570.

ECB (2018) Good governance in a changing environment, Newsletter article, 15 August, available at https://www.bankingsupervision.europa.eu/press/publications/newsletter/ 2018/html/ssm.nl180815.en.html.

ECB (2016) SSM supervisory statement on governance and risk appetite, June, available at https://www.bankingsupervision.europa.eu/ecb/pub/pdf/ssm_supervisory_statement_ on_governance_and_risk_appetite_201606.en.pdf.

A. Ezat \& A. El-Masry (2008) The impact of corporate governance on the timeliness of corporate Internet reporting by Egyptian listed companies, Managerial Finance 34 (12), 848-867. 
H. Farag \& C. Mallin (2017) Board diversity and financial fragility: Evidence from European banks, International Review of Financial Analysis 49, 98-112.

H. Farag \& C. Mallin (2018) The influence of CEO demographic characteristics on corporate risk-taking: Evidence from Chinese IPOs, The European Journal of Finance 24 (16), 1528-1551, doi: 10.1080/1351847X.2016.1151454.

K. A. Farrell \& P. L. Hersch (2005) Additions to corporate boards: The effect of gender, Journal of Corporate Finance 11 (1), 85-106.

Federal Reserve, Office of the Comptroller of the Currency, Office of Thrift Supervision, Federal Deposit Insurance Corporation (2010) Guidance on sound incentive compensation policies, June.

E. Garcia-Meca, I.-M. Garcia-Sanchez \& J. Martinez-Ferrero (2015) Board diversity and its effects on bank performance: An international analysis, Journal of Banking and Finance 53, 202-214.

G. Gorton \& R. Rosen (1995) Corporate control, portfolio choice, and the decline of banking, Journal of Finance 50, 1377-1420.

Group of Thirty (G30) (2012) Corporate Governance Working Group, Toward Effective Governance of Financial Institutions. Washington, D.C.

J. Hagendorff \& K. Keasey (2012) The value of board diversity in banking: Evidence from the market for corporate control, The European Journal of Finance 18 (1), 41-58.

D. C. Hambrick (2007) Upper Echelons Theory: An Update, Academy of Management Review 32 (2), 334-343.

B. E. Hermalin \& M. Weisbach (2003) Boards of directors as an endogenously determined institution: A survey of the economic literature, Economic Policy Review 9, 7-26.

A. J. Hillman, J. A. A. Cannella \& R. L. Paetzold (2000) The resource dependence role of corporate directors: Strategic adaptation of board composition in response to environmental change, Journal of Management Studies 37 (2), 235-255.

N. Huyghebaert \& L. Wang (2017) Value creation and value distribution in Chinese listed firms: The role of ownership structure, board characteristics, and control, The European Journal of Finance doi: 10.1080/1351847X.2017.1386704.

R. Kanter (1977) Men and Women of the Corporation. New York: Basic Books.

G. Kirkpatrick (2009) The corporate governance lessons from the financial crisis, OECD Financial Market Trends 2009/1, 1-30.

L. Laeven \& R. Levine (2009) Bank governance, regulation and risk taking, Journal of Financial Economics 93, 259-275.

J. Li \& Y. I. Tang (2010) CEO hubris and firm risk-taking in China: The moderating role of managerial discretion, Academy of Management Journal 53 (1), 45-68.

Liikanen Report (2012) High-level expert group on reforming the structure of the EU banking sector. Brussels, October.

C. Lin, P. Lin, F. M. Song \& C. Li (2011) Managerial incentives, CEO characteristics and corporate innovation in China's private sector, Journal of Comparative Economics 39 (2), 176-190.

Y. Liu, Z. Wei \& F. Xie (2014) Do women directors improve firm performance in China, Journal of Corporate Finance 28, 169-184.

H. Mehran, A. Morrison \& J. Shapiro (2011) Corporate governance and banks: What have we learned from the financial crisis? Federal Reserve Bank of New York, Staff Report 502, June.

M. Pargendler (2019) The grip of nationalism on corporate law, ECGI Working Paper $N^{\circ} 437$ / 2019, January.

S. Pathan (2009) Strong boards, CEO power and bank risk-taking, Journal of Banking and Finance 33, 1340-1350. 
K. Samaha, K. Dahawy, K. Hussainey \& P. Stapleton (2012) The extent of corporate governance disclosure and its determinants in a developing market: The case of Egypt, Advances in Accounting, Incorporating Advances in International Accounting 28 (1), $168-178$.

W. G. Sanders \& D. Hambrick (2007) Swinging for the effects: The effects of CEO stock options on company risk-taking and performance, Academy of Management Journal 50 (5), 1055-1078.

A. Saunders, E. Strock \& N. G. Travlos (1990) Ownership structure, deregulation, and bank risk taking, Journal of Finance 45, 643-654.

V. Sila, A. Gonzalez \& J. Hagendorff (2016) Women on board: Does boardroom gender diversity affect firm risk? Journal of Corporate Finance 36, 26-53.

A. Srivastav \& J. Hagendorff (2016) Corporate governance and bank risk-taking, Review of Corporate Governance 24 (3), 334-345.

S. Terjesen, R. Sealy \& V. Singh (2009) Women directors on corporate boards: A review and research agenda, Corporate Governance: An International Review 17, 320-337.

D. Walker (2009) A review of corporate governance in UK banks and other financial industry entities, Consultative Document, November.

J. D. Westphal \& E. J. Zajac (1995) Who shall govern? CEO/board power, demographic similarity, and new director selection, Administrative Science Quarterly 40, 60-83. 